\title{
La primera guerra mundial en el Boletín Oficial del Grande Oriente Español, 1914-1918
}

\author{
The First World War in the Official Bulletin of the Spanish Grand \\ Orient, 1914-1918
}

\author{
José Antonio Ferrer Benimeli \\ Universidad de Zaragoza, España \\ bibliotecasalvadorzaragoza@gmail.com
}

Recepción: 17 de febrero de 2018/Aceptación: 11 de marzo de 2018.

doi: https://doi.org/10.15517/rehmlac.v10i1.32453

Palabras clave

Gran guerra; relaciones internacionales masónicas; esfera pública; 1914-1918; masonería española.

Keywords

Great War; Masonic International Relations; Public Sphere; 1914-1918; Spanish Freemasonry.

Resumen

Aunque la guerra empieza el 28 de julio de 1914, el BOGOE no lo aborda oficialmente hasta el 31 de mayo de 1915 en la convocatoria a la gran asamblea de representantes. Esta fue presidida por Alberto de Lera y Álvarez, venerable de la logia Jovellanos de Gijón. Tras esta, las referencias a la guerra en el BOGOE se pueden clasificar en: 1) artículos de prensa masónica extranjera, traducidos, 2) noticias y avisos referidos entre otras al fracaso del pacifismo y de la masonería; a la iniciativa del G.M. de Bélgica ante las grandes logias de Alemania; y 3) asambleas generales de 1915 a 1918 con mensajes de presidentes, de los grandes maestres y propuestas sobre la guerra y la paz. El $B O G O E$ concluye con festivales masónicos en honor de la paz y de los aliados, así como con la propuesta de unificar las masonerías para la paz internacional.

Abstract

Although World War I began on July 28, 1914, the official Bulletin of Spanish Grand Orient, with a single exception, didn't mention it officially until May 31,1915 in a call for a meeting of representatives of the Great Assembly. This was presided by Alberto de Lera y Álvarez, venerable master of the Jovellanos Lodge of Gijón. After this meeting, references to the war in the bulletin are classified as follows: 1) translated articles from the masonic press abroad, 2) news and notices about, amongst others, the failure of pacifism and of Freemasonry; Belgium GM 's initiative towards the German Lodges, and 3) the general assemblies of 1915 to 1918 with messages from presidents, from Grand Masters and proposal about war and peace. The bulletin concludes with masonic festivals to honor peace and the allied forces, a well as with a proposal to unify all freemasonries for international peace.

\section{Introducción}

Siete meses antes del inicio de la primera guerra mundial el Boletín Oficial del Grande Oriente Español -en adelante BOGOE-, en su número del 30 de enero de 1914 ${ }^{1}$,

\footnotetext{
${ }^{1}$ Boletin Oficial del Grande Oriente Español [BOGOE] XXII, no. 261 (Madrid, 30 de enero de 1914): 5.
} 
tiene un significativo artículo titulado "Por la Paz de Méjico" en el que se recoge la comunicación que la Oficina Internacional de la Paz, con sede en Suiza ${ }^{2}$, había dirigido a los generales Huerta y Carranza ${ }^{3}$ interesándose por que "el reinado de la paz se estableciera prontamente en la República Mexicana".

Dicho documento es una llamada "en nombre de la Humanidad" para poner fin "al derramamiento de sangre y a la obra de muerte, de terror y de exterminio" que azotaba a Méjico. Concluye expresando los deseos de la Francmasonería del Grande Oriente Español por el cese de la guerra fratricida en México.

Una segunda alusión a la paz la encontramos el 26 de febrero ${ }^{4}$ en un discurso del $2^{\circ}$ vigilante de la logia Jovellanos no. 377 de Gijón, simbólico Riego ${ }^{5}$, leído en la tenida de instalación de cargos, en el que hay un párrafo bastante sintomático. Hablando de los efectos e influencia de la masonería en los pueblos -como el progreso y la alegría-carga el acento en el hecho de que allí donde la masonería tenía peso "cesan las contiendas, la paz toma estado y hasta el bienestar y la riqueza afluyen como por encanto". Y añadía: “¿Pruebas? Nos lo dicen todos los Estados del centro de Europa y Norteamérica cuya influencia masónica es decisiva".

Pocos meses después la primera guerra mundial empezaba precisamente en los estados del centro de Europa, si bien es cierto que Norteamérica sería la última en incorporarse un par de años más tarde.

Como es bien sabido la guerra se inició el 28 de julio de 1914 con la invasión de Bélgica por el ejército alemán. Sin embargo, el Boletín Oficial del Grande Oriente Español hasta el 29 de septiembre no empezó a ocuparse de ella y lo hizo en la "Parte no oficial" reproduciendo un artículo tomado de la revista masónica suiza Alpina que viene a ser el contrapunto al discurso de Alberto de Lera en la logia Jovellanos de Gijón. Se titula "Un cataclismo" y comienza aludiendo precisamente al "soplo de idealismo" que desde hacía unos años pasaba sobre la humanidad:

Por todas partes se venían efectuando tentativas de aproximación entre los pueblos. Parecía que las naciones marchaban felizmente hacia una era mejor, más fraternal, más humanitaria y caritativa.

Pero de pronto se desencadenó la guerra, la más terrible, la más desastrosa de las guerras, pues jamás en la historia de la humanidad se registran casos de que tantos pueblos hayan combatido unos contra otros ${ }^{6}$.

\footnotetext{
${ }^{2}$ Está fechada en Berna el 2 de enero de 1914 y firmado por el presidente Henry La Fontaine, premio Nobel de la Paz en 1913, profesor de derecho en Bruselas y vicepresidente del Senado belga.

${ }^{3}$ El general Victoriano Huerta era el presidente de la República mexicana, y el general Venustiano Carranza el jefe del partido constitucionalista, con residencia en Nogales, Arizona.

${ }^{4}$ BOGOE XXII, no. 262 (Madrid, 26 de febrero de 1914): 23.

${ }^{5} \mathrm{Sin}$ indicación de fecha. El simbólico riego corresponde a Francisco Castaño González.

${ }^{6}$ BOGOE XXII, no. 268 (Madrid, 29 de septiembre de 1914): 148.
} 
Es la primera alusión a la guerra, precisamente en el año que había sido designado para ser "el año de las aproximaciones de concordia y fraternidad". Miles de francmasones de Francia y Alemania se habían citado en Frankfurt los días 14 y 15 de agosto con el objeto de estrecharse las manos y trabajar con ardor y entusiasmo para conseguir una aproximación franco-alemana. Estaban previstos importantes congresos en diferentes ciudades con la finalidad de discutir los medios "de hacer desaparecer la guerra sustituyéndola por el arbitraje internacional". Además la Unión Interparlamentaria -la más importante de las agrupaciones pacifistas-debía reunirse en Estocolmo a fines de julio.

Repentinamente esas naciones que no deseaban otra cosa que vivir en paz se habían arrojado unas sobre otras. Y ante la reacción de quienes decían que esto era el fracaso del pacifismo se insiste en que "ahora es cuando se manifiesta como la obra más urgente que realizar".

Y tras recoger el comentario de los que decían que "esta guerra monstruosa" no era tan solo un fracaso del pacifismo sino también de la francmasonería, de las religiones, del cristianismo, de la moral y del derecho, oponiéndose a esta actitud, el articulista ${ }^{7}$ añade: "No, esto no es un fracaso de la Masonería. Más que nunca tiene ésta el imperioso deber de trabajar por la fraternidad de las naciones". Y recogiendo unas palabras del "hermano Henri Lafontaine", presidente del Bureau Internacional de la Paz: "nosotros los francmasones, debemos ser por principio, por ideal, por deber y por interés, luchadores infatigables de la paz", concluye el artículo diciendo que, a pesar de las trágicas circunstancias que atravesaban, la francmasonería proseguiría con decisión su obra fraternal pues "la desesperación y el desfallecimiento no son masónicos".

Hay que esperar al 30 de octubre -tres meses después del inicio de la guerra-para que el $B O G O E$ aluda a ella en la "parte oficial" del mismo, aunque lo hace indirectamente en una alusión un tanto decepcionante. Se trata de un aviso o recordatorio dirigido a "nuestros hermanos" que dice así:

Como los sucesos de la guerra distraen por completo la atención, nos permitimos recordar a nuestros hermanos el Decreto de nuestro Gran Maestre, de 12 de julio último, encareciéndoles la conveniencia de consagrar el 6 de diciembre próximo una Tenida blanca a la memoria de D. Juan Prim ${ }^{8}$.

En este mismo número del BOGOE, en su sección "Noticias" se recoge un breve artículo procedente también de la revista masónica suiza Alpina titulado “¿Enemigos y Hermanos!" que empieza con una información del Daily Telegraph, de Londres, calificada "como un rayo de sol en medio de las tinieblas y horrores que evoca la guerra actual". Allí

\footnotetext{
${ }^{7}$ Que corresponde a las iniciales A.I.T., siendo su traductor Servet, 33.

${ }^{8}$ BOGOE XXII, no. 270 (Madrid, 30 de octubre de 1914): 161. El homenaje tuvo lugar y el 31 de diciembre, no. 272, 199-200 el BOGOE ofrece una síntesis de los actos celebrados en Madrid, Barcelona, Sevilla, Gijón, Puerto Rico y Filipinas.
} 
se relata un hecho ya familiar en el anecdotario masónico tradicional. El de un prisionero masón que va a ser fusilado y hace la señal masónica de socorro, siendo reconocido como hermano por el oficial -también masón- que mandaba el pelotón de ejecución. Tras el reconocimiento viene el perdón y la libertad. La novedad es que en este caso, situado en Lovaina tras "el saqueo e incendio de la ciudad por los alemanes" eran cincuenta los prisioneros destinados a ser fusilados. Pero cuando el ciudadano en cuestión recibió la orden de salir de las filas de los prisioneros y marcharse libremente, éste se negó diciendo que "mis compatriotas no son más culpables que yo. Si los matáis, no me iré y sufriré la misma suerte que ellos". El desenlace es recogido así: "Emocionado el oficial alemán ante el hermoso acto de amor y patriotismo del ciudadano belga, mandó dar libertad a los cincuenta prisioneros, que debieron la vida a la intervención de un francmasón"9.

En este goteo de noticias indirectas sobre la guerra, en el Boletín del 30 de marzo de 1915 hay un breve suelto, al final del número, bajo el epígrafe de "Joffre es masón" en el que, según noticias comunicadas por la prensa masónica, "se asegura que el generalísimo Joffre, el caudillo de las fuerzas aliadas en la guerra actual, pertenece a nuestra Augusta Institución". Con ello daban respuesta "a los muchos hermanos que han manifestado deseos de saberlo" $"$.

Finalmente, el 31 de mayo de 1915 la cuestión de la guerra se aborda por primera vez en la parte oficial del Boletín Oficial del Grande Oriente Español ${ }^{11}$. Y lo hace el gran consejo de la orden en la convocatoria para el 14 de junio próximo de la gran asamblea de representantes que debía llevar a cabo la labor legislativa del Grande Oriente Español para ese año de 1915. Asamblea que estudiaría principalmente el tema de la guerra:

Cuando nos encontramos en presencia de la guerra más desastrosa que los siglos han conocido, cuando perecen millones de seres humanos y el espíritu de la destrucción se ha enseñoreado en las más importantes regiones de la Europa civilizada, olvidando los más elementales preceptos del derecho y de la fraternidad de los hombres, a la Francmasonería corresponde estudiar los medios más eficaces para impedir en lo sucesivo los dolorosos espectáculos que en el presente siglo presencia con horror la Humanidad ${ }^{12}$.

En el mismo número y en la "parte no oficial" se reproduce un "documento masónico interesante" del gran maestre del Gran Oriente de Bélgica, Charles Magnette, dirigido a fines de septiembre del año anterior a las nueve grandes logias de Alemania ${ }^{13}$ invitándolas a trabajar en común con el Grande Oriente de Bélgica con un objetivo: influir

\footnotetext{
${ }^{9}$ BOGOE XXII, no. 272 (Madrid, 31 de diciembre de 1914): 174-175.

${ }^{10}$ BOGOE XXIII, no. 275 (Madrid, 30 de marzo de 1915): 48.

${ }^{11} B O G O E$, Año XXIII, no. 277 (Madrid, 31 de mayo de 1915): 65-66.

${ }^{12}$ BOGOE, Año XXIII, no. 277 (Madrid, 31 de mayo de 1915): 65-66.

${ }^{13}$ Dicho documento fue enviado a través del consulado de Alemania en Lieja.
} 
en los países beligerantes tanto en la población civil como en los ejércitos para que todos tuvieran presente el deber de cumplir las leyes humanitarias que regulan el derecho de los pueblos y el de la guerra.

A este fin proponía el nombramiento de una comisión de masones de países neutrales a la que deberían sumarse "un hermano belga y otro hermano alemán" para que todos visitaran los territorios devastados por la guerra y reunieran sus observaciones.

Pero solo las grandes logias de Darmstadt y Bayreuth contestaron y ambas oponiéndose a la propuesta ${ }^{14}$. Las otras siete grandes logias guardaron silencio que fue interpretado como un rechazo a la proposición del gran maestre del Grande Oriente de Bélgica. Por su lado el gran maestre de la Gran Logia de Bayreuth declaró que no iba a recomendar a las tropas alemanas misericordia, bondad y moderación "porque la actitud de sus enemigos no se lo permitirá". A lo que su colega belga, lamentando semejante manera de pensar, respondió que la bondad y los sentimientos humanitarios eran cualidades altamente masónicas que no se debían ejercer únicamente entre los que tenían y demostraban los mismos sentimientos ${ }^{15}$.

El $B O G O E$ del 30 de junio de 1915 dedica la parte oficial a la gran asamblea de ese año, y a la guerra en la no oficial. Fue elegido presidente de la asamblea Alberto de Lera y Álvarez, venerable de la logia Jovellanos no. 337 de Gijón. El trabajo sobre la guerra lleva el título de "La guerra enseña" y está firmado por R. S. Viriato, desde Barcelona ${ }^{16}$. En realidad, tomando como ejemplo el caso de Bélgica de la que hace una detallada síntesis histórica, es un alegato contra "los catalanistas intransigentes, los que sueñan con la autonomía, la nacionalidad o la independencia, como lo quieran llamar, de la región”. El artículo concluye recordando el precepto masónico de cultivar los lazos de amor y fraternidad, y con el utópico deseo de que estos sean

los encargados de derribar fronteras, hermanar a los pueblos unos con otros, impedir que existan ambiciones bastardas que arrojan a Naciones en cruenta lucha y que no exista en el mundo más que un ideal, un amor y una bandera, que con sus pliegues recoja a todos los hombres de buena voluntad ${ }^{17}$.

\footnotetext{
${ }^{14}$ En el número anterior del BOGOE 276 (Madrid 29 abril 1915): 64, se alude a la negativa de estas grandes logias alemanas a constituir una comisión investigadora encargada de recorrer las regiones de Bélgica que habían sufrido las crueldades y destrozos originados con motivo de la guerra actual. Memoria que serviría para demostrar la veracidad de los hechos comunicados por la Prensa de todos los países.

${ }^{15}$ BOGOE XXIII, no. 277 (Madrid, 31 de mayo de 1915): 69-93.

${ }^{16}$ BOGOE XXIII, no. 278 (Madrid, 30 de junio de 1915): 84-85. Probablemente se trate del militar (comandante de infantería) Ramón Soriano Cardona, simbólico Viriato. Fue iniciado en la logia Redención de Barcelona (Gran Logia Simbólica Regional Catalano Balear). En 1915 fue uno de los fundadores de la logia Fénix también de Barcelona, bajo la obediencia del Grande Oriente Español, siendo uno de sus venerables y autor de El Libro del Masón, uno de los libros de instrucción más divulgados en la época en Cataluña. Información que debo y agradezco sinceramente a Pere Sánchez Ferré.

${ }^{17}$ BOGOE XXIII, no. 278 (Madrid, 30 de junio de 1915): 84-85.
} 
Al margen de artículos de opinión, más o menos discutibles o polémicos, aunque el hecho de que fueran publicados por el órgano oficial del Grande Oriente Español es suficientemente sintomático, tiene más interés conocer qué alusiones a la guerra existen en la memoria de la secretaría general ${ }^{18}$. Y allí, desde el primer párrafo, se abordan los acontecimientos desarrollados en Europa a partir de la última asamblea "dándoles un sentido moral y con la imparcialidad que acostumbramos emplear". Razón por la que querían manifestar que a los masones españoles "los pueblos beligerantes por igual, nos merecen respeto y cariño". Sin embargo, dadas las corrientes pacifistas de multitud de organismos mundiales les había cogido por sorpresa "las gigantescas proporciones alcanzadas por la actual contienda".

Y tras hacer un análisis de las causas y origen de la guerra, se incide en que todos los organismos sociales habían sufrido un marcado fracaso: el socialismo, las distintas asociaciones obreras, la plutocracia poseedora del capital, los distintos partidos políticos mundiales, la diplomacia, las religiones positivas... e incluso "el Creador de todas las cosas y Director del movimiento universal... el Dios de todas las religiones...”. Todos se habían convertido "en estatuas de sal, que se han disuelto al calor de la sangre vertida"19.

Respecto a la masonería universal "que se halla constituida por hombres conscientes y que por esta razón debiera tener a su cargo la dirección de la inteligencia humana, y que además en sus Códigos, lo mismo en el material que en moral, se impone como primera condición la misión de difundir la fraternidad universal ha fracasado también". Pero añadirá el secretario general en su memoria:

como los masones nos hallamos por nuestra voluntad dotados de un espíritu perseverante y tenaz para defender nuestros sublimes ideales, el fracaso presente debe servirnos de aviso y lección para imprimir mayores energías en nuestra cotidiana labor, a fin de ir formando una sociedad más caritativa y perfecta, que sepa rechazar las iniciativas de los ambiciosos, procurando establecer la justicia y la equidad mundial ${ }^{20}$.

La memoria concluye con una nueva alusión a la guerra y a la neutralidad adoptada por España que colocaba a los masones españoles en condiciones de "analizar la situación mundial con juicio sereno e imparcial precaviendo las contingencias del porvenir".

Con este objetivo el gran consejo de la orden había estudiado la manera de poner fin a la lucha armada "encomendando los litigios internacionales a una nueva forma diplomática mejor organizada y dispuesta que la actual, abrumada por sus constantes

\footnotetext{
${ }^{18}$ Que lleva la firma de Víctor Gallego, Gran Secretario General y está fechada en Madrid el 14 de junio de 1915.

${ }^{19}$ BOGOE XXIII, no. 279 (Madrid, 31 de julio de 1915): 102-111.

${ }^{20}$ BOGOE XXIII, no. 279 (Madrid, 31 de julio de 1915): 109.
} 
fracasos $^{21}$. Para ello el Grande Oriente Español se pondría al habla con la masonería mundial.

Del dictamen final a la memoria del secretario, en la parte relativa a la guerra, que es calificada de "hecatombe humana con sus múltiples aspectos de barbarie e inusitada crueldad y completo desquiciamiento de toda la secular labor humana" se destaca que la función de la masonería española debía ser cooperar "con potente voluntad e inquebrantable fe" por el futuro y definitivo imperio de "nuestra sacrosanta trilogía Libertad, Igualdad y Fraternidad", síntesis de las posibles dichas humanas"22.

Más adelante, en el capítulo de propuestas presentadas a la gran asamblea general, hay una ${ }^{23}$, titulada "Por la paz: medios de afirmarla en lo futuro" en la que, tras ratificarse el Grande Oriente Español" en la idea pacifista que informa el credo de la Francmasonería", se trata de los futuros mapas territoriales y se hacen unos planteamientos más o menos utópicos sobre el desarme general; el contingente de ejército regular máximo en cada nación (dos mil hombres por cada millón de habitantes); el equivalente en fuerzas navales de guerra (proporcional a la extensión de las costas y a las colonias respectivas); la resolución de todos los litigios internacionales por medio del arbitraje de una junta internacional (con un representante de cada nación), etcétera ${ }^{24}$.

Hasta el 30 de septiembre no vuelve a ocuparse de la guerra el Boletín Oficial del Grande Oriente Español, y lo hace en la sección de "Noticias" donde informa que el Comité Bernois de socorros a los prisioneros de guerra, en Berna (Suiza) estaba solicitando fondos para "su caritativa obra a favor de los desgraciados internados en varios campos de concentración". Dicho comité -añade- es una asociación suiza y neutral que asistía "tanto a los prisioneros de una nación como a los de la otra", y enviaba diariamente más de cien paquetes conteniendo "víveres, vestidos, tabaco y hasta juegos". Estaba reconocido oficialmente por todos los Estados beligerantes y trabajaba bajo los auspicios de la cruz roja suiza, siendo su presidente la "conocida escritora suiza Doña N. Valentin, y el secretario general D. Luis Gertsch, periodista muy conocido en España, especialmente en Barcelona, donde había sido delegado de la Asociación de la Prensa Internacional ${ }^{25}$. Precisamente los

\footnotetext{
${ }^{21}$ Sobre esta cuestión véase el trabajo de José Antonio Ferrer Benimeli, "Masonería y Pacifismo: La Sociedad de Naciones", en La masonería y su impacto internacional (Madrid: Universidad Complutense, 1989), 51-71; Ferrer Benimeli, "El Dr. Simarro y la masonería", Investigaciones psicológicas 4 (1987): 211-344; y Ferrer Benimeli, "La Sociedad de Naciones", en Masonería y Pacifismo en la España Contemporánea (Zaragoza: Prensas universitarias de Zaragoza, 1991), 105-126.

${ }^{22}$ BOGOE XXIII, no. 279 (Madrid, 31 de julio de 1915): 111. Sobre el mal uso del término trilogía, aplicado al lema "Libertad, Igualdad, Fraternidad". Ferrer Benimeli, Masonería, Iglesia, Revolución e Independencia (Bogotá: Universidad Javeriana, 2015).

${ }^{23}$ La número VI.

${ }^{24}$ BOGOE XXIII, no. 279 (Madrid, 31 de julio de 1915): 121.

${ }^{25}$ Sobre el masón y teósofo Luis Gertsch, que había sido en Barcelona gran secretario de la Gran Logia Española, consúltese el trabajo de Pere Sánchez Ferré, La maçoneria a Catalunya 1868-1947 (Barcelona: Clavell, 2008), donde existe abundante información.
} 
donativos debían enviarse bien a la Legación de España en Berna o entregarse en el Banco Español del Río de la Plata, en Barcelona, a nombre del secretario Dr. Luis Gertsch ${ }^{26}$.

En esta misma línea, otra breve noticia se refiere al "socorro a los belgas" protagonizado por la masonería del Canadá que había acordado que cada uno de los hermanos que la formaba contribuyera por lo menos con un dólar y así constituir un fondo destinado al socorro de los belgas. De esta forma el gran maestre y demás autoridades masónicas de las logias canadienses habían recogido y enviado la suma de cuarenta mil dólares al rey Alberto, que agradeció "acto tan filantrópico",27.

El primer boletín del Grande Oriente Español del año 1916, fechado el 31 de enero, se abre haciendo "fervientes votos por que en el año actual renazca potente y esplendorosa la aurora de la paz y terminen para siempre los horrores de la guerra que tantas víctimas ocasiona y tan destructores efectos viene produciendo en el suelo de Europa". Mensaje oficial que concluye con la invocación: “¡Paz, Paz entre los hombres, y formemos en el porvenir una inmensa familia de hermanos!" 28 . Firman el vicepresidente primero del Gran Consejo de la Orden, Antonio López del Villar; el gran comendador Dr. Luis Simarro, y el gran secretario general, Víctor Gallego ${ }^{29}$.

En el número 30 de abril el $B O G O E$ aporta, en la sección de "Noticias", los nombres de nueve masones italianos ${ }^{30}$ muertos en el campo de batalla frente a los austríacos. La información está tomada de la Revista Masónica del Gran Oriente Italiano. El Grande Oriente Español solicitó una triple batería de duelo a la memoria de estos "héroes de la libertad y de la patria".

En este goteo de referencias a la guerra el $B O G O E$ del 30 de junio de 1916 trae la noticia de que en París se acababa de constituir por personalidades distinguidas de todos los países neutrales, entre ellos las naciones americanas, España, Suecia, Holanda y Suiza, un comité internacional encargado de promover suscripciones en todo el mundo para erigir un monumento conmemorativo de las víctimas inocentes de los submarinos alemanes" "que sufrieron las consecuencias del extremo horror de esta trágica guerra ${ }^{32}$.

\footnotetext{
${ }^{26}$ BOGOE XXIII, no. 281 (Madrid, 30 de septiembre de 1915): 167.

${ }^{27}$ BOGOE XXIII, no. 281 (Madrid, 30 de septiembre de 1915): 167.

${ }^{28}$ BOGOE XXIV, no. 285 (Madrid, 31 de enero de 1916): 1.

${ }^{29}$ Este debió de ser su último acto oficial, pues en el siguiente $B O G O E$ del 29 de febrero, hay un decreto aceptando por unanimidad la dimisión de Víctor Gallego Barrientos (simbólico Castilla) "por encontrarse procesado masónicamente".

${ }^{30}$ Los nombres son Germano Manini, Vincenzo Sammartiano, Belisario Conti, Eduardo Amode, Cesare Mattocci, Orlando Maffei, Alfredo Allegre, Gustavo Folinea y Vito Valveri. BOGOE XXIV, no. 288 (Madrid, 30 de abril de 1916): 63. Unos meses después, el 31 de julio, el BOGOE completaba la lista anterior con otros ocho masones de la Familia italiana: Severino Severini, Giuseppe Bevilacqua, Nicolo Cebele, Roberto Prunas, Pascuale Luise, Epifanio Mattana, Girolamo Spinnato y Vincenzo Poniatoschy. BOGOE XXIV, no. 291 (Madrid 31 de julio de 1916): 135.

${ }^{31}$ Una de las más conocidas en España fue el compositor y pianista Enrique Granados y Campiña (1868-1916) muerto en el hundimiento del vapor Sussex, torpedeado por los alemanes el 20 de marzo de 1916, cuando regresaba del estreno en Nueva York de su ópera Goyescas. Enrique Granados fue uno de los más de
} 
En la asamblea general del Grande Oriente Español de 1916, celebrada el 12 de junio, el mensaje de Miguel Morayta como gran maestre está dedicado casi exclusivamente a la guerra que constituye el argumento vertebral del mismo. Empieza aludiendo al proyecto del gran maestre del Grande Oriente Lusitano Unido, Magalhaes Lima, de reconstituir la federación de la masonería latina, así como a los pasos que de común acuerdo habían dado unos años antes, estableciendo contactos con el gran maestre del Grande Oriente de Francia, y los grandes orientes de Italia, Rumanía y algunos de la América española. Pero cuando iban a presentar dicho proyecto en el congreso masónico que debía celebrarse en Roma, en 1912, la epidemia de cólera que "por los días señalados para su reunión segaba tantas vidas en aquella capital" hizo que muchos representantes no acudieran, entre ellos los del Grande Oriente Español.

Aplazado el propósito para el congreso que dos años después había de reunirse en Lisboa, se suspendió por la proclamación de la República portuguesa y el comienzo de la "actual gigantesca guerra".

A continuación Morayta hace unas reflexiones sobre el dualismo existente en la gran familia masónica, pues aunque la masonería es una y ley suya la universalidad, y "todos los masones del mundo queremos lo mismo" la mayoría no puede sustraerse fácilmente a los intereses materiales y políticos del pueblo en que vive. Y si bien el masón debe estimar en igual grado al masón del norte que al masón meridional, esta diferencia común a todas las naciones- impone deberes especialmente a los masones de una misma lengua.

El ejemplo más sintomático traído por Morayta es el de "nuestros hermanos del Centro de Europa" que en varias ocasiones habían celebrado asambleas masónicas para tratar aspectos particulares. En una de ellas, la federación de las grandes logias germánicas había acordado el $1^{\circ}$ de junio de 1914 -antes de la declaración de la guerra- "que cooperar directamente con el movimiento pacifista moderno no entraba en el cuadro de los trabajos masónicos". En consecuencia se ordenó a todas las grandes logias, logias y grupos masónicos "abstenerse de adherirse al movimiento pacifista". Esto sucedía -insiste Morayta- antes de penetrar los alemanes en Bélgica. La consecuencia inmediata fue la ruptura de relaciones con la masonería italiana y francesa ${ }^{33}$.

Tras dos años de guerra - dirá Morayta- el mundo estaba dividido y enfrentado. Por una parte Alemania, Austria, Turquía y Bulgaria. Y enfrente Inglaterra, Rusia, Francia, Servia, Montenegro e Italia; y en la medida de lo posible, dada su situación geográfica, Japón y Portugal.

setecientos firmantes del Manifiesto titulado "La guerra europea. Palabras de algunos españoles" promovido en septiembre de 1915 por el Dr. Simarro, soberano gran comendador y fundador de la Liga Española para la defensa de los derechos de hombre y del ciudadano.

${ }^{32}$ BOGOE XXIV, no. 290 (Madrid, 30 de junio de 1916): 95.

${ }^{33}$ BOGOE XXIV, no. 291 (Madrid, 31 de julio de 1916): 101-103. 
A continuación el gran maestre español hace una breve y realista síntesis de la situación:

Ni cuando las invasiones de los Bárbaros, ni en las luchas napoleónicas, alcanzó la guerra a tantas y tan extensas regiones; ni en ningún momento de la Historia fue tan brutal. Se combate sobre el suelo, bajo tierra, en el aire, en las aguas de los mares y en sus profundidades; y se mata con balas y metralla, con granadas, con bombas y con gases asfixiantes, con cuantos inventos descubrieron las ciencias físicas y químicas; muchas veces cuerpo a cuerpo, a la bayoneta, con granadas de mano y otras a quince y más kilómetros de distancia, desde donde ni aun es posible distinguir al enemigo. Y cual si estos horrores no bastaran, se fusilan rehenes, se arrasan pueblos, se saquea sin escrúpulo, se viola sin tasa, se destruyen maravillas artísticas, se bombardean desde los mares pueblos indefensos, y en suma, se hacen buenas las depreciaciones (sic) de vándalos y hunos. ¡Maldita, maldita guerra, baldón de los comienzos del siglo XX!

La conclusión de Morayta es clara: "Fracasaron los Tratados internacionales, los pactos de La Haya y Ginebra, el equilibrio europeo, el socialismo internacional, el servicio militar voluntario y hasta la Fraternidad masónica... destruyendo el fruto del trabajo mundial acumulado durante muchos siglos y matando millones de hombres..."34.

Dejando de lado otras interesantes cuestiones abordadas en la parte final relativas a la postguerra, Morayta afirma que el día de la paz, aunque muy lejano, llegará y ya triunfe el imperialismo alemán, ya venzan los aliados, la labor para ajustarla será inmensa. Pues habrá que abordar las reclamaciones de las nacionalidades belga y serbia -con perfecto derecho a recobrar su independencia- así como el resurgimiento de Polonia y la rectificación de las fronteras de Francia, Rusia, Turquía y Estados pequeños del centro de Europa, así como la anexión del vasto imperio colonial alemán en poder de los aliados... A esto habrá que añadirse las indemnizaciones de guerra y de los daños causados, las relaciones económicas de los pueblos beligerantes y de los neutrales, etc., etc., etc.

Y así como, a excepción de los germanos, únicos preparados para la guerra, los demás pueblos combatientes no lo estaban, la misma impresión existe ahora para la paz. En esta situación, se pregunta el gran maestre Morayta si la masonería hubiera podido establecer la confraternidad entre los pueblos caso de haber llevado a cabo la proyectada Confederación de los masones latinos. Para a continuación responderse: "No, la Masonería no lo hubiera podido todo, pero sí prestar algún concurso, algún apoyo apreciable a la tan deseada paz"35.

Las últimas palabras del discurso de Morayta - que fallecería cinco meses despuésson una especie de su propio testamento al pedir a los masones del Grande Oriente Español

\footnotetext{
${ }^{34}$ BOGOE XXIV, no. 291 (Madrid, 31 de julio de 1916): 102.

${ }^{35}$ BOGOE XXIV, no. 291 (Madrid, 31 de julio de 1916): 103.
} 
que defendieran con energía en los próximos congresos masónicos la federación masónica latina e incluso que tomaran la iniciativa de organizar un congreso de todos los orientes latinos $^{36}$.

En el capítulo de proposiciones presentadas a la asamblea general hay una de la logia Constancia de Zaragoza, fechada el 25 de mayo de 1916, titulada "Paz entre todos los hombres de buena voluntad"37. Presidida por el preceptivo lema "A la Gloria del Gran Arquitecto del Universo", y con la vista puesta en el porvenir de la Humanidad, "una vez terminada la actual, horrorosa y fratricida lucha" presentan una propuesta dividida en dos capítulos. En el primero: que el Grande Oriente Español se relacione con todas las Potencias masónicas de los países neutrales y a ser posible también con los de los beligerantes para en lo futuro "sentar sólidas y duraderas bases de paz universal o por lo menos crear los cimientos para su afianzamiento". Y en el segundo: tratar de conseguir la reunión de una magna Asamblea mundial representada por "todas las entidades masónicas regulares", es decir, "las que tienen el lema común que encabeza estos trabajos".

A continuación especifican en cinco apartados cuales consideran las bases más firmes para una futura paz:

$1^{\text {a }}$ Régimen diplomático parlamentario, frente al actual de diplomacia secreta.

$2^{\mathrm{a}}$ Arbitraje internacional obligatorio.

$3^{a}$ Institución del régimen proteccionista por el libre cambio, a base del impuesto único en lo tributario.

$4^{a}$ Autonomía absoluta de los pueblos y las razas, para que se rijan por sí propios, y

$5^{\text {a }}$ Tendencia a desvirtuar por la democracia los poderes absolutos y personales basados en la fuerza, puesto que ésta no sirve para crear y sí solo para destruir ${ }^{38}$.

En el número del 30 septiembre de 1916 del BOGOE y en la parte no oficial vuelven a ocuparse de la cruz roja suiza y del "Comité Bernois" de socorros a prisioneros de guerra creado en diciembre de 1914 en Berna como "un ramo de la Cruz Roja suiza". Su finalidad era la ayuda moral y material a los prisioneros de guerra necesitados, tanto en los campos de concentración, como en los repatriados y hospitalizados en Suiza ${ }^{39}$. Dada la situación geográfica de Suiza los envíos individuales de ropa, víveres y sobre todo pan llegaban en un tiempo relativamente corto.

Aunque la junta central del comité estaba en Berna se habían creado juntas locales en Ginebra, Lausana, Basilea, Viena, Locarno y Lugano. Hasta julio de 1916 habían realizado un conjunto de 150000 envíos. Pero a medida que la guerra se prolongaba el

\footnotetext{
${ }^{36}$ BOGOE XXIV, no. 291 (Madrid, 31 de julio de 1916).

${ }^{37}$ BOGOE XXIV, no. 291 (Madrid, 31 de julio de 1916): 115-116.

${ }^{38}$ BOGOE XXIV, no. 291 (Madrid, 31 de julio de 1916): 115-116.

${ }^{39}$ BOGOE XXIV, no. 293 (Madrid, 30 de septiembre de 1916): 163-164. Un año antes, el 30 de septiembre de 1915, el BOGOE se había ya ocupado del comité Bernois de ayuda a los prisioneros de guerra. Véase la nota 26.
} 
número de prisioneros aumentaba y los fondos recogidos en Suiza se agotaban, por lo que apelaban a las personas caritativas de otros países, especialmente latinos neutrales ya que su ayuda era "absolutamente indispensable" $"$.

El 31 de octubre informa el BOGOE que por una concesión especial del Parlamento británico, las logias masónicas eran "las únicas sociedades secretas permitidas en la Gran Bretaña en los actuales tiempos de guerra" ${ }^{\text {"41 }}$.

A continuación trae otra noticia titulada "Una opinión autorizada". Se trata de una carta escrita por el gran maestre de la Gran Logia de Hungría y catedrático de la Universidad de Budapest, de la que extraen el siguiente párrafo:

Yo deseo hacer constar claramente que el masón, sea cualquiera el país a que pertenezca, tan solo por una aberración de su mentalidad puede volverse guerrero. En verdad, la Masonería es la unión mundial de paz, caridad y humanidad; su ideal, por tanto, es la paz y la inteligencia mutua entre hombres y naciones, y uno de sus ideales es el desarme universal y la paz perpetua ${ }^{42}$.

En el número siguiente, del 30 noviembre 1916, y en la parte oficial del BOGOE, el gran maestre Dr. Miguel Morayta firma un clarificador mensaje dirigido a todos los cuerpos y talleres de la Federación del Grande Oriente Español. Empieza así:

El imperialismo prusiano creó en cuarenta años de persistentes trabajos una máquina militar potentísima, y su adoración por la fuerza le inspiró la creencia de que los soldados y los cañones lo pueden todo.

Cegado por su desapoderado orgullo, consideró trabajo de pocos días su triunfo en toda la línea, sin comprender que su inicua invasión del Luxemburgo y de la Bélgica desataría la guerra europea, que necesariamente había de despertar en toda su integridad la antigua cuestión de Oriente, compendio de tantos y tan múltiples problemas, adormidos por el pavor que inspiraba una conflagración universal ${ }^{43}$.

Tras dibujar los retrocesos y horrores ${ }^{44}$ si el imperialismo alemán salía airoso en su empeño, Morayta afirma con claridad que "por fortuna los aliados triunfarán" lo que aseguraba un porvenir de ventura y bienandanza que compensaría a la larga "los inmensos sacrificios hechos por los beligerantes de uno y otro bando y por los pueblos que voluntaria o forzosamente observaron severa neutralidad".

\footnotetext{
40 Los bancos a los que podían remitirse los donativos eran: Banque Nationale Suisse, Berna; Crédit Lyonnais, París; National City Bank, Nueva York; y Banco Español del Río de la Plata, Buenos Aires y Barcelona.

${ }^{41}$ BOGOE XXIV, no. 294 (Madrid, 31 de octubre de 1916): 183.

${ }^{42}$ BOGOE XXIV, no. 294 (Madrid, 31 de octubre de 1916): 183-184.

${ }^{43}$ BOGOE XXIV, no. 295 (Madrid, 30 de noviembre de 1916): 185-186.

44 "Derivados de las diferencias de razas, de religión, de lengua, de límites geográficos, de independencia nacional y de intereses materiales".
} 
No obstante - añadirá- a la paz habrán de seguir años de mucha confusión y de extraordinaria gravedad por la lucha de intereses e ideas. Y es allí donde la masonería podía hacer mucho. Razón por la que Morayta encarecía a todos los triángulos, logias y grandes logias de la federación que prepararan una memoria para la próxima asamblea sobre el siguiente tema: “¿Qué puede y debe hacer la Masonería para que, una vez terminada la actual guerra europea, continúen desarrollándose ordenadamente los principios de libertad y de progreso característicos de este siglo XX?"

Por su parte la secretaría general daba a conocer el acuerdo tomado el 20 de noviembre 1916 por el gran consejo de la orden en la sesión celebrada los días 4 y 18 de ese mismo mes, a saber:

Comunicar a las Potencias Masónicas de nuestras relaciones la actitud de la Masonería Española con respecto a las causas que defienden las naciones beligerantes en la guerra actual, declarando reconocer que los aliados luchan por el triunfo de los ideales de Libertad, Progreso y Confraternidad universal, cuyos principios informan el credo de nuestra Augusta Institución ${ }^{45}$.

Un par de meses después el BOGOE del 31 de enero 1917 en las primeras páginas, con una gran fotografía y esquela daba la noticia del inesperado fallecimiento, a los 82 años, del gran maestre, Miguel Morayta y Sagrario (13 de septiembre de 1834-18 de enero de 1917), simbólico Pizarro, al que dedican gran parte del número con su biografía política, académica, periodística y masónica, así como a su entierro en el cementerio civil. Sin embargo el Boletín inicia la parte oficial con el mensaje del $1^{\circ}$ de enero del gran maestre interino José Lescura ${ }^{46}$ al comenzar el nuevo año de 1917 . Mensaje en el que el Gran Consejo de la Orden y el Supremo del grado 33 de la Federación del Grande Oriente Español,

hacen fervientes votos por que en el año actual renazca potente y esplendorosa la aurora de la Paz y terminen para siempre los horrores de la guerra que tantas víctimas ocasiona y tan destructores efectos viene produciendo en el suelo de Europa.

Concluye con un sentido deseo: “¡Paz, Paz entre los hombres, y formemos en el porvenir una inmensa familia de hermanos!"47.

\footnotetext{
${ }^{45}$ BOGOE XXIV, no. 295 (Madrid, 30 de noviembre de 1916): 187.

${ }^{46}$ Firman el documento José Lescura, gran maestre en ejercicio y vicepresidente $1^{\circ}$ del gran consejo de la orden; el Dr. Luis Simarro, gran comendador; y el secretario general Enrique Gras. Un día después del fallecimiento de Morayta, José Lescura quedó encargado oficialmente de la gran maestría hasta la reunión de la próxima gran asamblea.

${ }^{47}$ BOGOE XXV, no. 297 (Madrid, 31 de enero de 1917): 2.
} 
La siguiente información relacionada con la guerra aparece en el número del $B O G O E$ del 31 de marzo de $1917^{48}$. Se refiere a la logia Jovellanos de Gijón y a cómo practicaba "sus deberes fraternales". Y lo hace dando a conocer lo sucedido en el puerto de Gijón en los últimos días del mes de enero cuando llegaron traídos por una goleta inglesa veinticinco náufragos procedentes de un vapor italiano "torpedeado por los submarinos alemanes"49.

En el momento de desembarcar, uno de los miembros de la Jovellanos, por indicación del venerable, "cumpliendo con los humanitarios e ineludibles deberes que impone la Orden hizo el signo de reconocimiento que fue inmediatamente advertido por algunos de los náufragos. Entonces se dieron a conocer como masones el capitán y el primer maquinista del buque "torpedeado" y el capitán de la goleta que los condujo al puerto de Gijón. A partir de ahí se les prodigaron toda clase de atenciones, y se les ofreció "hospitalario hospedaje" en los domicilios de los hermanos de la logia Jovellanos. Pero con "la mayor cortesía y agradecimiento" fueron rehusados pues estaban ya convenientemente atendidos por el cónsul de su nación. No obstante durante los días que permanecieron en Gijón hasta el regreso a sus hogares fueron acompañados por los hermanos de la logia que les prestaron toda su ayuda ${ }^{50}$.

Un mes más tarde, el $B O G O E$ del 30 de abril reproduce los últimos decretos del gran consejo de la orden, y entre ellos, un preocupante mensaje del gran maestre en funciones Eduardo Barriobero ${ }^{51}$ dirigido a todas las logias españolas poniéndolas en guardia ante el peligro de que España perdiera su neutralidad:

\footnotetext{
${ }^{48}$ BOGOE XXV, no. 299 (Madrid, 31 de marzo de 1917): 47-48.

${ }^{49}$ En realidad, según el relato del capitán del vapor italiano "Taormin", el submarino alemán les obligó a parar. Una vez los marinos italianos en dos grandes botes salvavidas, registrado -y parece ser que saqueado en busca de víveres- el barco italiano fue hundido por los alemanes que colocaron varias bombas antes de desaparecer. El hundimiento tuvo lugar a las siete y ocho minutos de la tarde del 12 de enero 1917 a 50 millas al sur del cabo Lizard (Inglaterra). El "Taormin" tenía 1.525 toneladas de registro y cargaba 3500. Había salido de Génova donde estaba matriculado. Llevaba a bordo 3100 toneladas de mineral de hierro que había recogido en Benisaf (Argelia) con destino a Newport. Los 25 náufragos estuvieron remando trece horas hasta las 8 de la mañana del día siguiente cuando divisaron la goleta inglesa "W.M.L." que se dirigía a Gijón con cargamento de caolín para la fábrica de Loza, y los recogió. El Noroeste. Diario Democrático XXI, no. 7178 (Gijón, 25 de enero de 1917): 1-2.

${ }^{50}$ BOGOE XXV, no. 299 (Madrid, 31 de enero de 1917): 47-48. Un mes después, en abril, El Masón Moderno de La Habana comentaba así esta noticia en un suelto titulado "En honor de la logia Jovellanos": Hemos leído el relato de un suceso fraternal de resonancia mundial, ocurrido entre unos veinte supervivientes de un vapor italiano torpedeado y hundido por los heróicos, fidalgos y aplaudidos submarinos del Kaiser alemán y la benemérita logia Jovellanos, de Gijón. Esta, como siempre se ha hecho acreedora al aplauso de todos los que amamos la Masonería, porque la conocemos. ¡Hurra! por la Logia Jovellanos de Gijón”. BOGOE XXV, no. 303 (Madrid, 31 de julio de 1917): 131.

${ }^{51}$ A la muerte de Morayta fue designado gran maestre interino José Lescura. Pero, debido a un largo viaje que debía realizar por Murcia, Cartagena y Andalucía -requerido por asuntos profanos- nombró a su vez a Eduardo Barriobero Herrán como su sustituto en virtud de los reglamentos en vigor, ya que en esos momentos desempeñaba el cargo de primer vicepresidente del Gran Consejo de la Orden. BOGOE XXV, no. 299
} 
Para ningún buen masón puede pasar inadvertida la gravedad de los momentos actuales. A punto estamos de tomar parte activa en la guerra más formidable que la humanidad ha conocido, y frente a esta posibilidad son indispensables una gran fortaleza de espíritu, una robustez de conciencia, y una imperturbable presencia de ánimo, circunstancias que, por desgracia, no caracterizan a los que en España desde hace tiempo vienen administrando la cosa pública.

Y más adelante añadía:

Los buenos masones no pueden permanecer indiferentes ante tan lamentable estado de cosas; de hoy más nuestras logias, y especialmente las domiciliadas en territorio español, no cumplirán sus deberes con solo reunirse y practicar de un modo estricto y literal lo que nuestros rituales preceptúan; es preciso elevar algo más el espíritu y el pensamiento, y así lo han entendido muchas de aquellas respetables entidades que han tenido a bien dirigirse al Gran Consejo de la Orden y a la Gran Maestría en demanda de una orientación ${ }^{52}$.

En consecuencia dio la orden de realizar en todas las logias una memoria que reflejara el estado de la opinión pública respecto a la guerra europea detallando qué beligerantes tenían mayor número de adeptos, si los "intervencionistas o los pacifistas". También era fundamental expresar la condición social de los que formaban cada grupo ${ }^{53}$.

En el mismo número se inserta, en la sección de noticias, una tomada del Boletín del Bureau Internacional de relaciones masónicas correspondientes al mes de febrero que titulan "Conferencia masónica interaliada". Allí se informa que los masones de la región parisina pertenecientes a las dos obediencias masónicas francesas se habían reunido el 16 de enero en el gran templo de la rue $\mathrm{Cadet}^{54}$ en una tenida "excepcionalmente numerosa" presidida por los hermanos Georges Corneau [sic] y el general Peigné ${ }^{55}$. Asistieron delegados y altos dignatarios de las naciones aliadas: Bélgica, Italia, Servia, Portugal...

Una de las intervenciones más notable, según el $B O G O E$, fue la del profesor Richet, miembro del instituto ${ }^{56}$, acerca del tema "Asociación de Naciones" en el que propuso que "a la terminación de la guerra actual" el arbitraje internacional obligatorio debía ser una de

(Madrid, 31 de marzo de 1917): 33. Finalmente el 9 de junio fue definitivamente elegido como gran maestre, el Dr. Simarro. BOGOE XXV, no. 303 (Madrid, 31 de julio de 1917): 101-102.

${ }^{52}$ BOGOE XXV, no. 300 (Madrid, 30 de abril de 1917): 50.

${ }^{53}$ BOGOE XXV, no. 300 (Madrid, 30 de abril de 1917): 50, una interesante respuesta a esta encuesta realizada por la logia Abora no. 331 de Santa Cruz de La Palma, en Ferrer Benimeli y Manuel De Paz Sánchez, Masonería y pacifismo en la España contemporánea (Zaragoza: Universidad, 1991), 94-96.

${ }^{54}$ Bajo los auspicios del consejo de la orden del Grande Oriente de Francia y del Supremo Consejo del Rito Escocés.

${ }^{55}$ Unas líneas más abajo es designado general Pigné.

${ }^{56}$ Charles Richet (1850-1935), médico francés, miembro del Instituto de Francia y de la Academia de Medicina, pertenecía a la logia Cosmos de la Gran Logia de Francia. Había sido Premio Nobel de Medicina en 1913. 
las condiciones de la paz futura. A su vez el general Peigné propuso -y la Asamblea aceptó por unanimidad- que se enviara un mensaje a los ejércitos aliados que él mismo presentó ya redactado con el título de "Salud a los ejércitos aliados" como justo tributo de admiración,

a los soldados de los valientes ejércitos que luchan que sufren y soportan las mayores miserias y privaciones, que mueren, en fin, no por ambición de conquista, sino por el triunfo del ideal masónico y de progreso, de justicia y de protección a los débiles y oprimidos, de todo lo que constituye la gran fraternidad humana. ¡Saludemos a los supervivientes! ¡Viva la fraternidad masónica! ${ }^{57}$

También se acordó celebrar otro congreso masónico interaliado en el próximo mes junio convocado por el Gran Oriente de Francia en el que serían invitadas las potencias masónicas de los países neutrales ${ }^{58}$.

Efectivamente el Grande Oriente Español había recibido la correspondiente invitación que fue aceptada adhiriéndose a dicho congreso masónico al que decidió enviar una representación de tres delegados. El 30 de abril se designaron el Dr. Luis Simarro y Eduardo Barriobero, "reservándose el nombramiento de un tercero para más adelante" ${ }^{\natural 9}$.

Por esas fechas, según el órgano oficial de la masonería suiza, en su número del 30 de abril, había "más de un millón de combatientes en la guerra actual que pertenecen a la masonería", cifra que resulta difícil de creer a falta de pruebas más convincentes. De esta noticia se hacía eco el $B O G O E$ del 31 de mayo ${ }^{60}$.

Eduardo Barriobero en su último mensaje como gran maestre interino en la asamblea general del Grande Oriente Español de $1917^{61}$, no ocultó su clara postura antigermánica y pro aliada. Barriobero se decanta por los aliados, entre otras razones por "las afinidades de raza y comunidad de intereses" que España tenía con Francia, Inglaterra y Portugal. Algunos párrafos de este Mensaje son elocuentes:

Determina el crimen cometido con Bélgica el que la Humanidad se divida en dos bandos, el de los partidarios de la libertad y respeto al derecho escrito de una parte y de otra los partidarios de la fuerza irracional, de la alevosía submarina y aérea, y del Kartel como procedimiento comercial, encumbrador del fuerte y asesino del débil...

\footnotetext{
${ }^{57}$ BOGOE XXV, no. 300 (Madrid, 30 de abril de 1917): 62-63.

${ }^{58}$ BOGOE XXV, no. 300 (Madrid, 30 de abril de 1917): 62-63. Esta tenida terminó con la ejecución de la Marsellesa y de los himnos nacionales de las Potencias aliadas, cantados por el M. Noté, de la Opera.

${ }^{59}$ BOGOE XXV, no. 300 (Madrid, 30 de abril de 1917): 62-63.

${ }^{60}$ BOGOE XXV, no. 301 (Madrid, 31 de mayo de 1917): 79.

${ }^{61}$ Tuvo lugar el 9 de junio 1917, el mismo día en que fue elegido como gran maestre del GOE el Dr. Luis Simarro.
} 
Debemos fomentar en todos los españoles la convicción de que estamos obligados a prestar los auxilios materiales y espirituales que sean compatibles con nuestra miserable situación a los afines de raza, a los que luchan por salvar a la humanidad del azote teutón ${ }^{62}$.

Entre los acuerdos adoptados por la asamblea general del GOE, el primero fue suprimir la celebración del banquete de clausura teniendo en cuenta "las circunstancias luctuosas en que se halla Europa con motivo de la guerra actual"63.

En el mismo número del $B O G O E$ y en la sección "Noticias" hay una que lleva el título de "Los masones americanos y la guerra" en la que se alude a la entrada de Norteamérica en la guerra, que había tenido lugar el 2 de abril $1917^{64}$. Con este motivo los masones americanos "reconociendo los altos principios de libertad y democracia" que habían impulsado a América a declarar la guerra al Imperio alemán ${ }^{65}$, acordaron adherirse a la política internacional de los Estados Unidos y hacer todo lo posible "para ayudar al Estado a proseguir hasta un fin victorioso". A continuación el BOGOE reproduce la declaración del gran maestre de la Gran Logia de masones del Estado de Nueva York, Thomas Penny: "Nosotros debemos hacer nuestra parte en el trabajo que nos confronta en el mundo, y tenemos que contribuir liberalmente para aminorar el sufrimiento de la Humanidad".

A esta sigue el acuerdo tomado por la Gran Logia de Nueva York:

Por cuanto que los Estados Unidos de América, en armonía con los antiguos principios de libertad y justicia sobre los cuales está basado su Gobierno, y en apoyo de las libertades de los pueblos y el derecho de todas las naciones, por pequeñas que sean, a gobernarse por sí mismas libres de la agresión de Estados más poderosos, ha entrado en esta gran guerra y ha desenvainado la espada en defensa de la democracia contra la autocracia que amenaza los principios del Gobierno propio por los cuales nuestros antepasados lucharon y murieron; y ha declarado su intención de llevar la lucha a una conclusión victoriosa, libre de motivos mercenarios o ambiciosos de engrandecimiento territorial; por lo tanto:

Se acuerda que nosotros, la Gran Logia de Libres y Aceptados Masones del Estado de Nueva York, en su convención anual reunida, juramos al Gobierno de los Estados Unidos nuestro incondicional apoyo y ofrecemos a nuestro país nuestros mejores esfuerzos, nuestras fortunas y nuestras vidas, a fin de que la victoria corone nuestros esfuerzos y que el gobierno del pueblo, por el pueblo y para el pueblo, no perezca en la tierra ${ }^{66}$.

\footnotetext{
${ }^{62}$ BOGOE XXV, no. 303 (Madrid, 31 de julio de 1917): 103-107. Sobre los germanófilos y aliadófilos en España. Ferrer Benimeli, “E1 Dr. Simarro y la masonería”, Investigaciones psicológicas 4 (1987): 211-344.

${ }^{63}$ BOGOE XXV, no. 303 (Madrid, 31 de julio de 1917): 123.

${ }^{64} \mathrm{El}$ pretexto fue la destrucción de navíos de guerra americanos por los submarinos alemanes.

${ }^{65}$ Wilson dio a su intervención el sentido de una cruzada por la libertad y la democracia.

${ }^{66}$ BOGOE XXV, no. 303 (Madrid, 31 de julio de 1917): 131.
} 
A partir del mes de agosto el $B O G O E$ empieza a sufrir también las consecuencias de la guerra a juzgar por el aviso que desde entonces va a encabezar todos los números hasta mayo de 1918. En él se advierte que en atención a la alarmante escasez de existencia de papel en adelante y hasta que "terminen las presentes circunstancias" el Boletín solo constará de ocho páginas ${ }^{67}$.

Sin embargo llama la atención que en los números que van de agosto a noviembre prácticamente la mitad del Boletín está dedicado a reproducir una larga conferencia leída en la logia Casablanca no. $346^{68}$ por el h. Luis Herrero titulada "La fatalidad de la guerra" que quiere ser una respuesta a la pregunta con la que se inicia: "¿Qué nuevos problemas sociales aparecerán después de la Gran Guerra, y cual deberá ser la actuación de la Masonería Universal ante ellos?"69

En el Boletín de agosto se da también información del congreso masónico de las Naciones Aliadas y neutras, celebrado en París los días 28, 29 y 30 de junio en el que estuvieron representados: Gran Oriente de Francia, Gran Colegio de Ritos de dicho Gran Oriente, Gran Logia de Francia, Supremo Consejo de Francia, Gran Oriente de Italia, Supremo Consejo de Italia, Gran Logia Simbólica Italiana, Grande Oriente Español, Gran Logia Suiza Alpina, Supremo Consejo de Suiza, Gran Priorato Independiente de Helvecia, Gran Oriente Lusitano Unido, Gran Oriente de Bélgica, Supremo Consejo de Bélgica, Supremo Consejo de Servia, Supremo Consejo del Rito Escocés de la República Argentina, Gran Oriente Argentino, Gran Oriente y Supremo Consejo del Estado de Río Grande del Sur (Brasil) y Gran Logia de Arkansas. Además remitieron adhesiones la Gran Logia de Costa Rica y la Gran Logia de Ohio, EE.UU. ${ }^{70}$.

Los tres representantes del Gran Oriente Español fueron Simarro, Salmerón ${ }^{71}$ y Vinaixa, éste último designado por la Gran Logia Catalana-Balear que formaba parte de la Federación del Gran Oriente Español.

En los primeros meses de 1918, es decir hasta el 31 de marzo, la única alusión a la guerra en el $B O G O E$ procede a una noticia sobre "Los masones de Turquía". Allí se dice que casi todas las potencias masónicas europeas poseían logias masónicas en Turquía, si bien los trabajos en las mismas se hallaban suspendidos con motivo de la guerra actual.

\footnotetext{
${ }^{67}$ Este aviso aparecerá desde el no. 304 del mes de agosto de 1917 al no. 313 del 31 de mayo 1918. Antes, normalmente tenía 21 páginas, incluidas las del Suplemento de Información Reglamentaria.

${ }^{68}$ La logia Casablanca no. 346 había sido fundada el 9 de julio de 1913 y fue la primera de las once logias que el GOE creó en Marruecos entre esa fecha y el 13 de noviembre de 1920 que fundó en Tánger la logia Minerva no. 416. Ferrer Benimeli, "Las logias del Gran Oriente Español (1900-1936)", en Masonería, política y sociedad, coord. Ferrer Benimeli (Zaragoza: CEHME, 1989), Tomo II, 1031-1082.

${ }^{69}$ BOGOE XXV, no. 304 (31 de agosto de 1917): 137-140; no. 305 (30 de septiembre de 1917): 144-148; no. 306 (31 de octubre de 1917): 152-154; no. 307 (30 de noviembre de 1917): 158-159.

${ }^{70}$ BOGOE 307 (30 de noviembre de 1917): 135.

${ }^{71}$ No se especifica el nombre. Por supuesto no se trata de Nicolás Salmerón y Alonso (1837-1908) y mucho menos de su hermano Francisco (1822-1878). Debe de tratarse de José Salmerón García, ingeniero, hijo de don Nicolás, con nombre simbólico D’Alembert, iniciado en la logia Ibérica de Madrid en 1913. Desempeñó cargos de confianza en el Gran Oriente Español.
} 
Pero dado el entusiasmo que aquellos hermanos tenían hacia la institución era seguro que "tan pronto como cesen estas circunstancias la labor masónica adquirirá toda su fuerza y vigor". Afirmación hecha desde la logia Perseverancia de la obediencia del Gran Oriente Español $^{72}$.

En el mes de abril 1918 el BOGOE destaca otra noticia titulada "Buen masón y buen patriota" tomada de la prensa francesa, Journal Officiel. Se refiere a Charles-Nicolas Bernardin "presidente del extinguido Comité Masónico de aproximación franco-alemana". Habiendo dirigido todas las reuniones celebradas con este objeto sufría en esos momentos "la mayor desilusión y desencanto con motivo de la guerra". El hermano Bernardin era juez de paz en Pont-à-Mouson desde hacía más de diez y nueve años. Pertenecía también al consejo de notables y delegados de las obras de asistencia pública y había prestado a la población servicios de excepcional importancia. En justo premio a sus merecimientos acababa de ser nombrado caballero de la orden de la legión de honor ${ }^{73}$.

En este goteo de pequeñas noticas alusivas a la guerra el $B O G O E$ del 31 de mayo ${ }^{74}$ vuelve a ocuparse de la Oficina Internacional de Relaciones Masónicas, fundada en 1902 por la Gran Logia Suiza Alpina cuya sede estaba en Neuchâtel y que era reconocida por toda la masonería internacional. Entre sus funciones estaba el socorro a los masones prisioneros durante la guerra y a la aproximación de los grupos masónicos.

La gran asamblea de 1918 centra el $B O G O E$ del 30 de junio. Entre las proposiciones presentadas hay una relativa a la actuación que debía adoptar la masonería en el orden internacional, lógicamente dedicada a la guerra ${ }^{75}$. Allí se abordan cinco puntos: 1) La necesidad de afianzar y estrechar los lazos de unión entre la masonería española y la de aquellos pueblos que luchaban por la causa de la libertad y la justicia. 2) Ratificar la simpatía con que todo el GOE seguía los esfuerzos de los países aliados en defensa de su existencia amenazada, así como la fe inquebrantable de la masonería española en "el triunfo definitivo de la razón y el derecho contra la barbarie imperialista". 3) Trabajar con tesón por la formación de la Sociedad de Naciones propuesta por el Presidente Wilson ${ }^{76}$. 4) Entretanto procurar por todos los medios que se constituya un organismo integrado por representantes de todos los pueblos democráticos, que con el nombre de Gran Oriente

\footnotetext{
${ }^{72}$ BOGOE XXV, no. 311 (Madrid, 31 de marzo de 1918) 24. En 1920 todavía existía en Salónica la logia Perseverancia, fundada en 1907. En 1909 el Gran Oriente Español tenía otras tres logias en Andrinópolis, Constantinopla y Salónica. En este mismo número del BOGOE hay otras dos breves noticias un tanto curiosas: La elección de Colville Smith como gran maestre de Inglaterra, y la existencia de 24 logias de negros en California con un total de 780 obreros (lo que hace una media de unos 32 miembros por logia).

${ }^{73}$ Sobre este personaje, consúltese Jean-Claude Couturier, Charles Bernardin. Figure emblématique du Grand Orient de France (Estrasburgo: ed. Messene, 2001).

${ }^{74}$ BOGOE XXVI, no. 313 (Madrid, 3 de mayo de 1918): 39.

${ }^{75}$ BOGOE XXVI, no. 314 (Madrid, 30 de julio de 1918): 55. Se trata de una síntesis de las muchas contestaciones habidas al cuestionario enviado para el estudio de las logias acerca de la actuación que debía adoptar la masonería en el orden internacional. Véase la nota 53.

${ }^{76}$ Sobre la Sociedad de Naciones y la masonería, lar revísese la obra citada Masonería y Pacifismo en la España contemporánea, 105-126.
} 
Universal puede intervenir activamente cerca de los gobiernos para obtener que los conflictos entre Naciones se resuelvan por medio del arbitraje. 5) Que la masonería española procure ser lazo de unión entre la alemana y la de los otros países que luchan en el imperio central, para que cuando termine la guerra "vuelva la masonería teutona a los principios fundamentales de nuestra Orden".

Un mes más tarde el BOGOE del 31 de agosto reproduce íntegro el largo mensaje que el gran maestre, Dr. Simarro, había dirigido a la gran asamblea del año 1918. Está dedicado única y exclusivamente a la guerra mundial y a la paz universal. En él se pregunta:

¿Qué va a suceder después de esta guerra? No hay duda alguna que el mundo sufrirá una profunda y fundamental transformación. Si venciera el espíritu de violencia y dominación, la civilización se detendría sin duda alguna y se produciría una regresión medieval más profunda que todas las causadas...

Para añadir a continuación:

Por el contrario, si se afirmara e impusiera el ideal de la paz, libertad, democracia e independencia de los pueblos, la lógica histórica exigiría un nuevo e inconmensurable desarrollo de estos principios, no solo en las relaciones internacionales, sino en el gobierno interior de cada Estado.

Después de hacer un detallado análisis de los motivos y principios que habían llevado a cada país a involucrarse en la guerra, sugiere que

los intereses nacionales, que muchas gentes, ciegas para el ideal, consideran como los solos motivos de la política internacional, no podrían explicar esta coalición de 23 naciones que habitan continentes diversos, hablan lenguas distintas, tienen historias diferentes y no pueden tener en modo alguno intereses comunes, ya que el interés es por su naturaleza un sentimiento egoísta, separador y exclusivo. Solo un ideal democrático de libertad, de paz y de justicia ha podido reunir en una coalición formidable a casi todos los pueblos libres del mundo ${ }^{77}$.

Dirigiéndose más en particular a los masones, Simarro añade que

El ideal humanitario, pacifista, de libertad, igualdad y fraternidad que pone sobre todas las cosas del mundo el Derecho, la justicia y el Amor entre todos los hombres, que es precisamente el ideal masónico, que todos conocéis y habéis jurado defender, constituye hoy la bandera común de los 23 pueblos y naciones que luchan contra el

\footnotetext{
77 Fuera habían quedado, aparte las repúblicas de Chile y Argentina "dominadas por influencias ultraconservadoras y clericales", los pueblos más pequeños del mundo (Estados escandinavos, Holanda y Suiza) y "nuestra España, que hasta ahora no ha dado muestras de enterarse de la magnitud y el sentido de esta guerra, que es en realidad una verdadera revolución democrática, segundo acto de la revolución francesa de 1789, BOGOE XXVI, no. 316 (Madrid, 31 de agosto de 1918): 80.
} 
espíritu de dominación, oligárquico, militarista y fomentador de los odios nacionales que representan los imperios absolutos de Alemania y Austria Hungría y el despotismo oriental de Turquía.

No faltan las alusiones a Rusia convertida durante la guerra "por la lógica inmanente de la Historia en una República federal"78, y a la República federal de los Estados Unidos que, al otro lado del Atlántico lejos de los campos de batalla de Europa, había tomado las armas "no por históricos rencores, no por intereses comerciales ni ventajas económicas, sino por puros motivos ideales".

En esta parte final del discurso de Simarro vuelve a estar presente la Sociedad de Naciones propuesta por Wilson como fin de la guerra, así como la organización de un ejército internacional "que sostuviese con la fuerza el derecho reconocido y declarado de los pueblos"79.

Las últimas palabras del gran maestre ante esta mundial tragedia "la más enorme, la más monstruosa que nunca se viera en la historia humana", acaban con una pregunta: “Será necesario decir a los francmasones dónde está su puesto en esta universal revolución?" 80

Unos meses más tarde, el 30 de noviembre, el $B O G O E$, que ni siquiera recoge el fin de la guerra que había tenido lugar el día 11 de ese mismo mes, sí trae una breve y última noticia sobre una "notable conferencia” que con el título "¿Cómo la guerra se puede evitar?" había pronunciado en la logia Redención, de Barcelona, el Venerable José Soldevilla Canela, presidente de la Gran Logia Simbólica Regional Catalano-Balear ${ }^{81}$.

El BOGOE cierra el año 1918 con un mensaje oficial "a todos los Grandes Orientes, Grandes Logias y Supremos Consejos de nuestras relaciones; a los Cuerpos, Delegaciones, Miembros de Honor, Garantes de Amistad, Representaciones, Talleres, Triángulos y masones de la Federación". Y lo hace con estas palabras:

El Gran Consejo de la Orden y el Supremo del grado 33 de la Federación del Grande Oriente Español, al comenzar el nuevo próximo año de 1919, en el que afortunadamente para la Humanidad, se avecina una era de paz, os desean S.E.P. [Salud.Estabilidad.Poder.] y os envían su felicitación y cariñoso abrazo fraternal ${ }^{82}$.

\footnotetext{
${ }^{78}$ Simarro, en 1919 , tomaría partido en contra del bloqueo internacional que se pretendía establecer en Rusia a fin de crear dificultades e incluso la caída del régimen que la revolución bolchevique de 1917 había implantado en aquel país. Ferrer Benimeli, "El Doctor Simarro y la masonería", 240-242.

${ }^{79}$ Aquí trae la experiencia positiva que se acababa de realizar en Francia donde bajo el mando único del general Foch combatían juntos franceses, ingleses, americanos e italianos.

${ }^{80}$ BOGOE XXVI, no. 316 (Madrid, 31 de agosto de 1918): 77-81.

${ }^{81}$ BOGOE XXVI, no. 316 (Madrid, 31 de agosto de 1918): 112.

${ }^{82}$ Está fechado en Madrid el 31 de diciembre de 1918. Lo firman el gran maestre, presidente del consejo de la orden, Dr. Luis Simarro, gr. 33. El soberano gran comendador, pro tempore, Enrique Gras Morillo, gr. 33, y el gran secretario general, José Lescura Borrás, gr. 33. BOGOE XXVI, no. 320 (Madrid, 31 de diciembre de 1918): 113 .
} 
En este mismo número del BOGOE, y último del año 1918, hay una relación del Festival Masónico celebrado “en honor de la paz y de los aliados". Había tenido lugar el 4 de diciembre en el teatro Benavente de Madrid, organizado por el Gran Oriente Español en conmemoración del armisticio "en el que se consagró la victoria de los pueblos por la Libertad, la Democracia y la Justicia social, contra el imperialismo y el militarismo".

El local, según la relación oficial del acto, "estaba exornado con lujo y buen gusto, y en el escenario se había colocado un estrado severo, con algunos atributos y símbolos masónicos". Empezó la sesión con una intervención del gran maestre, Dr. Simarro, que presidía la sesión, quien hizo una extensa relación histórica del desarrollo de la masonería en el mundo, a partir del siglo XVIII en Inglaterra, donde su organización llegó a perfeccionarse, extendiéndose por toda la humanidad. Tras citar a los "grandes caudillos liberales españoles masones", pasó a hablar de la labor de la oficialidad francesa que vino a España en los ejércitos de Napoleón "y defendió por toda la nación la obra de la Masonería"; y acabó relacionando aquellos tiempos con los presentes pintando a grandes rasgos lo que significaba la victoria de los aliados "en bien de las ideas fundamentales de Libertad, Igualdad y Fraternidad”.

A continuación habló el h. Marcelino Domingo que exaltó la hora de la paz como momento del triunfo de las ideas contra la fuerza, "del sentimiento contra el cálculo, del genio latino contra la organización imperialista y militarista".

El h. Mario Roso de Luna ocupó después la tribuna, pronunciando "un notable discurso", explicando la alta significación moral e intelectual de la Masonería, "que defiende la fraternidad entre todos los hombres y pone como ideales supremos por cima de todas las querellas de los hombres la Verdad, la Justicia y la Libertad". Pidió para España como salvación de su decadencia una obra de cultura, de amor entre todos sus hijos, de verdadera democracia. Exaltó a Francia, "que durante el curso de la Historia ha sido víctima de la ambición de tiranos y siempre se ha cumplido el Destino, frustrando sus planes y derrotando a los que quisieron sojuzgarla y humillarla”. Terminó elogiando a Italia y a los Estados Unidos ${ }^{83}$.

Después habló D. Indalecio Prieto, pronunciando una "vibrante oración” ensalzando la solemnidad del acto y poniendo de relieve la corrección y delicadeza con que los partidarios de los aliados celebraban el triunfo de sus pueblos favoritos y de sus ideas. Hizo una reflexión sobre qué hubiera ocurrido si los vencedores hubieran sido los alemanes, dada su política agresiva y sus instintos de dominación. Cantó la Libertad y el Progreso, y pidió que España se incorporara a la Sociedad de Naciones, "democratizándose ella por su propio esfuerzo, sin que nos lo impusieran poderes extraños".

\footnotetext{
${ }^{83}$ Roso de Luna, ya había sido requerido, el 24 de febrero de 1917, por la logia Isis y Osiris no. 377, de Sevilla, para que les diera por escrito su opinión sobre el siguiente tema "¿Qué puede y debe hacer la masonería para que una vez terminada la actual guerra europea continúen desarrollándose adecuadamente los principios de Libertad y progreso característicos de este siglo XX?".
} 
Volvió a tomar la palabra el gran maestre, Dr. Simarro, quien hizo un breve resumen de las intervenciones, elogiando a Wilson y su programa de la Liga de Naciones. Concluyó dando las gracias a todas las personas que habían honrado con su presencia el acto.

La reseña oficial concluye diciendo que los oradores fueron muy aplaudidos. Finalmente una orquesta ejecutó los himnos de los países aliados, que fueron ovacionados, vitoreándose con gran entusiasmo a los respectivos países especialmente a Italia y Francia. La Marsellesa fue repetida "entre delirantes manifestaciones de aplausos". También se oyeron vítores al presidente Wilson. La concurrencia al acto fue muy selecta, viéndose en ella numerosas señoras y nutridas representaciones de las Colonias extranjeras. "La velada del Gran Oriente Español resultó muy solemne y lucida" ${ }^{\sharp 4}$.

No pocas fueron igualmente las logias que conmemoraron y celebraron la paz. Así la logia Morayta no. 284, de Tánger, dirigió sentidos mensajes a los ministros de las Naciones aliadas con sede en Tánger "con motivo de la terminación de la guerra, y el triunfo de la causa de los aliados, que significa la victoria de la Libertad, de la Razón y del Derecho de la Humanidad".

Los representantes diplomáticos de Estados Unidos, Gran Bretaña, Bélgica, Francia, Italia y Portugal contestaron al mensaje de la logia Morayta en términos muy cordiales, agradeciendo las manifestaciones de afecto y simpatía de los masones de Tánger por la causa que habían defendido y defendían sus respectivos países ${ }^{85}$.

Por su parte la logia Aurora no. 234, de Cartagena, organizó el 18 de diciembre "un suntuoso banquete en el Gran Hotel en celebración de la paz, al que asistieron todos los obreros de aquel Taller y en cuyo acto reinó gran entusiasmo". Estrechamente unidos prosigue la reseña oficial- "merced al espíritu de confraternidad que anima a dichos hermanos se pronunciaron breves pero elocuentes discursos, abogando por que la próxima formación de la Liga de las Naciones responda al engrandecimiento y progreso de la Humanidad. De la celebración de dicho acto se dio conocimiento a los cónsules de las Naciones aliadas en Cartagena, así como a las autoridades masónicas de la región, en sendos y "expresivos telegramas de salutación"

Y respondiendo a la iniciativa del delegado del oriente español en Marruecos, se celebró en Tánger, en el Hotel Cecil, un gran banquete, al que asistieron las logias

\footnotetext{
${ }^{84}$ BOGOE XXVI, no. 320 (Madrid, 31 de diciembre de 1918): 115-116. En la memoria de la gran secretaría general presentada a la gran asamblea de 1919, por José Lescura, hay una referencia directa a la participación del diputado D. Indalecio Prieto, quien "entusiasmó al numerosísimo auditorio, que hasta de pie, en los pasillos exteriores e interiores del teatro asistieron, unos, por conocer la Masonería, los más, por ver si era cierto que nuestra labor no era la que nuestros enemigos propagaban con la beatífica idea de restarnos adeptos. Aquel diputado, con la elocuencia que le caracteriza no defraudó las esperanzas de los oyentes, pues aunque no es masón consagrado, lo es en el corazón, y lo exteriorizó constantemente durante su peroración. BOGOE XXVII, no. 326 (Madrid, 30 de junio de 1919): 47.

${ }^{85}$ BOGOE XXVII, no. 321 (Madrid, 31 de enero de 1919): 8.

${ }^{86}$ BOGOE XXVII, no. 321 (Madrid, 31 de enero de 1919): 8.
} 
españolas Morayta, Alb-el-Azis y Clemenceau, en unión de los componentes de la logia francesa Nouvelle Volubilis, la inglesa Coronation, y la italiana Concordia. Banquete que tuvo por objeto festejar el advenimiento de la paz. Al acto que resultó "muy brillante" asistieron cerca de cien comensales, "reinando la mayor cordialidad y regocijo entre ellos". La cena concluyó con un brindis por la paz mundial y por la unión de los masones ${ }^{87}$.

El tema de la paz y conclusión de la guerra tuvo, lógicamente, un lugar destacado en la memoria de la secretaría general, presentada a la asamblea de 1919 por José Lescura. Tras felicitar a las naciones que "con su esfuerzo, con su valor, con la fuerza que les había dado la razón, el derecho y la justicia, lema por el que habían luchado tan denodadamente durante cuatro años consecutivos, hasta lograr la victoria completa sobre los Imperios Centrales", concluía así, José Lescura, su referencia a la guerra y a la paz:

a todos los habitantes de las naciones vencedoras, un recuerdo cariñosísimo para las nobles víctimas del furor, de la locura desatada de los enemigos, y la expresión del ansia de que esta hecatombe mundial que nuestros ojos han visto en nuestros días, sea la última en la historia de la Humanidad, y los eminentes estadistas que hoy se ocupan en preparar las bases para la paz futura, tengan el acierto necesario para concretarla en términos que nunca jamás pueda pueblo alguno confiar a la suerte de las armas la resolución de sus ambiciones o las venganzas de mal sentidas pasiones de amor propio.

En esa misma asamblea se presentaron unas cuantas proposiciones relativas a solicitar la pronta celebración de un congreso masónico universal, para conseguir la más perfecta unidad masónica a fin de lograr en lo futuro la paz perpetua en beneficio del progreso de la humanidad. El propio consejo de la orden presentó una de ellas, suscrita por su gran secretario, y las restantes por las logias Fénix, Fraternidad Española, Palafox, Patria, Obreros Unidos y el capítulo Integridad ${ }^{88}$.

Dichas proposiciones fueron unificadas, pues con pequeñas diferencias todas iban dirigidas al mismo fin. Tras justificar la necesidad y oportunidad de la unificación de la masonería "haciendo desaparecer la clasificación de regulares e irregulares", creían llegado el momento oportuno de crear una verdadera familia unida por el lazo fraternal, a fin de trabajar "por aproximar unos pueblos a otros y crear el espíritu de solidaridad humana que permita en lo por venir solucionar todas las diferencias por procedimientos arbitrales":

Nuestro Oriente podría iniciar trabajos en este sentido, dirigiendo una carta a los de Francia, Bélgica y Logia de Francia, Orientes de Italia y Portugal, invitándoles a que, con motivo de la terminación de la guerra que tantas anormales circunstancias creó en las relaciones de todos los países, interpongan su influencia y su

\footnotetext{
${ }^{87}$ BOGOE XXVII, no. 327 (31 de julio de 1919): 84.

${ }^{88}$ BOGOE XXVII, no. 326 (30 de junio de 1919): 59.
} 
intervención con los masones americanos e ingleses que radiquen ahora en París, con motivo de las Conferencias interaliadas y se dirijan, además, al Oriente Americano, para que éste entable relaciones de franca y verdadera relación con ellos y con nosotros, a fin de establecer una Federación de las Masonerías interaliadas y la Española, que tanto demostró desde el principio de la guerra estar al lado de aquellas, con el fin de que seamos un núcleo verdaderamente potente, que establezca la verdadera relación entre las Masonerías regulares, y se terminen todas las masonerías irregulares...

Finalmente se aprobó la idea pero se insistió en el aspecto de la paz internacional:

Que se procure la creación de un organismo masónico internacional con el carácter de arbitral para la resolución de todos aquellos problemas de orden social y económico que a veces lanzan a la guerra a las naciones en lucha fratricida, pudiendo modificarse en tal sentido y llevando a su seno las correspondientes representaciones el organismo actualmente formado bajo la denominación de Bureau Internacional de relaciones masónicas ${ }^{89}$.

Y con motivo del Mensaje y felicitación del nuevo año del Gran Consejo de la Orden y del Supremo del Grado 33 de la Federación del GOE, fechado el 31 de diciembre de 1919, ambas instituciones, al terminar el año 1919 desean S.E.P. en el año próximo y envían su felicitación y cariñoso abrazo fraternal.

Hacen también fervientes votos por que en el año 1920 se consolide la Paz y terminen para siempre los horrores de la guerra que tantas víctimas ocasionó y tan destructores efectos produjo en el suelo de Europa.

¡Paz, Paz entre los hombres, y formemos en el porvenir una inmensa familia de hermanos! $!^{90}$

\section{Fuentes}

Boletín Oficial del Grande Oriente Español [BOGOE], Madrid, 1914-1919.

\section{Bibliografía}

Couturier, Jean-Claude. Charles Bernardin. Figure emblématique du Grand Orient de France. Estrasburgo: ed. Messene, 2001.

\footnotetext{
${ }^{89}$ BOGOE XXVII, no. 326 (30 de junio de 1919): 59.

${ }^{90}$ BOGOE XXVII, no. 332 (Madrid, 31 de diciembre de 1919):123. Mensaje que reproduce casi textualmente el del año 1916, revísese la nota 28.
} 
Ferrer Benimeli, José Antonio y Manuel de Paz Sánchez. Masonería y pacifismo en la España contemporánea. Zaragoza: Universidad de Zaragoza, 1991.

Ferrer Benimeli, José Antonio. "El Dr. Simarro y la masonería”. Investigaciones psicológicas 4 (1987): 211-344.

Ferrer Benimeli, José Antonio. "Las logias del Gran Oriente Español (1900-1936)". En Masonería, política y sociedad. Coordinado por José Antonio Ferrer Benimeli. Zaragoza: CEHME, 1989.

Ferrer Benimeli, José Antonio. "Masonería y Pacifismo: La Sociedad de Naciones". En La masonería y su impacto internacional. Coordinado por José Antonio Ferrer Benimeli. Madrid: Universidad Complutense, 1989.

Ferrer Benimeli, José Antonio. Aproximación a la masonería a través de sus lemas y divisas. Oviedo: Masonica.es, 2016.

Ferrer Benimeli, José Antonio. Masonería, Iglesia, Revolución e Independencia. Bogotá: Universidad Javeriana, 2015.

Ferrer Benimeli, José Antonio. "El Dr. Simarro y la masonería". Investigaciones psicológicas 4 (1987): 211-344.

Pozuelo Andrés, Yván. La masonería en Asturias (1931-1939). Oviedo: Universidad de Oviedo, 2012.

Sánchez Ferré, Pere. La maçoneria a Catalunya 1868-1947. Barcelona: Clavell, 2008. 